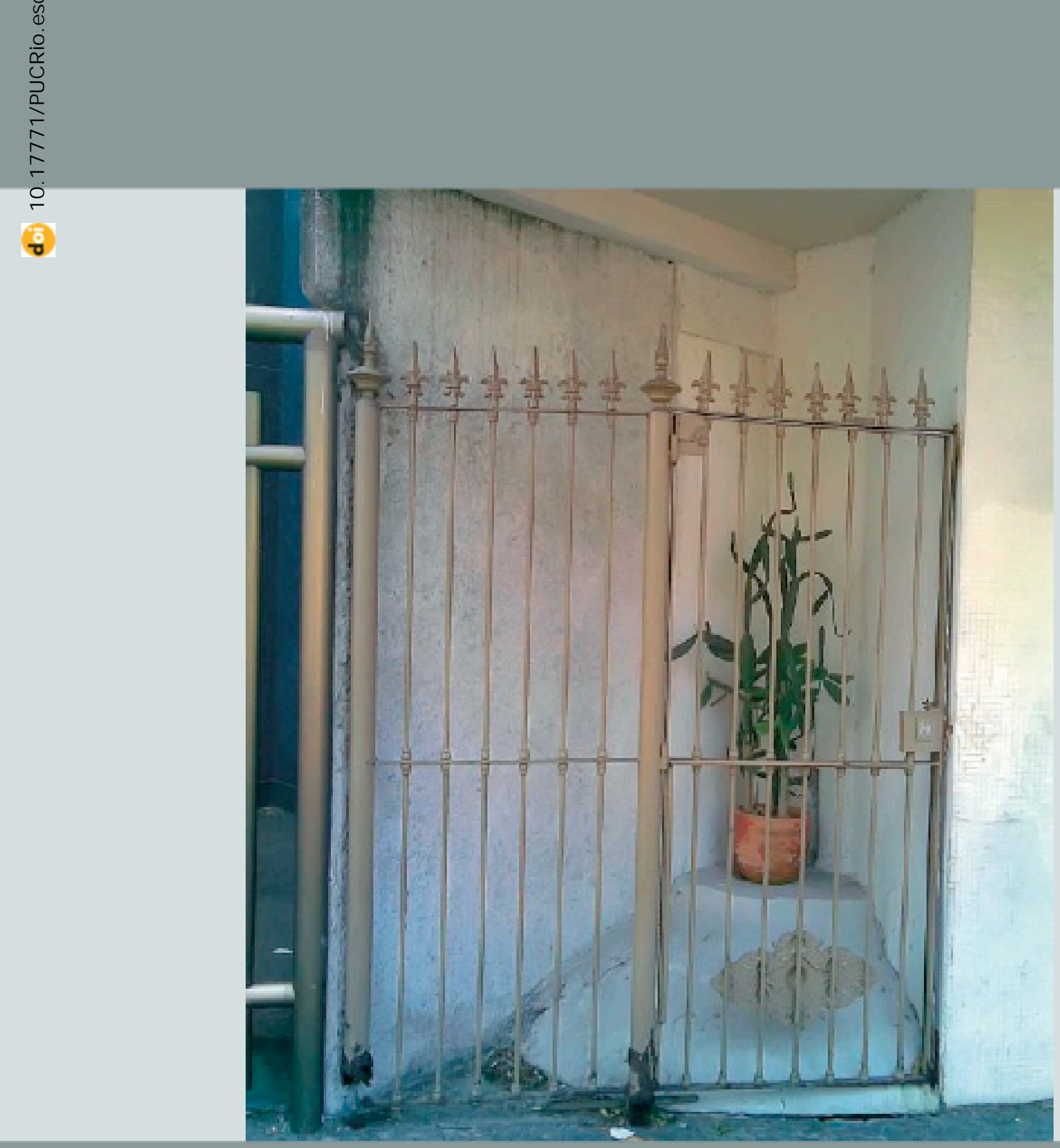

\title{
Gata no telhado
}

Acordei e estava viva - atônita. Num pulo, subi no telhado. Nenhum devaneio poupou-me de seu peso gigante. 0 imenso terraço árido espelhava meus olhos de chuva. $\mathrm{O}$ acordar diário era a execução daquilo a que chamava eu. E, ao anoitecer, a constatação de um renascimento em retalhos mal ajambrados do meu couro naquele tamborim.

Um pulo sem aviso, uma idéia que me toma de assalto, o gato no convés do navio. Presa no telhado cinzento, as sombras do que eu poderia ter sido apodrecem nos cantos de pó. Assim como meus sonhos, que não cabiam em lugar algum. Algo desconectou-se deixando partes de mim sem sentido.

À palavra, como existência primeira, retorno. Cada saída, um muro, cada volta, um tombo. Mancho de vinho 0 antigo robe de seda. Vestígios misturam-se em nuances pálidas de irrealidade. A carta numa garrafa vazia. 0 fio comprido de ausência, o novelo sempre a um passo. Encurralada no telhado, fora daqui não sei se existo. Lá fora, a ficção iminente. Sôfrega e desesperada por carne viva, encontrei apenas o telhado raso e vazio. Eo brilho metálico da palavra fria onde não há negação.

Busco o puro instinto que me leve além do telhado. Sozinha, aliso as fissuras no concreto. Suas bordas enriçam meu medo e resto faminta na sombra. Não acredito em deuses. Acredito na ausência da dor.

Gata que anda em círculos pelo telhado. Retornar ao que é original e único. Inelutável graça de sós nascermos e morrermos. 0 amor de fuga colorida pula no terraço e a desperta para a noite de sonho. Tons vivos que desbotam no sol ríspido da manhã frugal - grand finale previsivel na solidão úmida de resto no copo vazio. Medo traído pelo meio sorriso, abandono com pena cada devaneio. A cumprir meu recomeço, caminho sozinha entre as sombras do telhado. 